\title{
A study of micro finance institution's role in developing the small scale enterprises of Ethiopia
}

\author{
Anubha Srivastava ${ }^{1}$ and Preeti Kulshrestha ${ }^{2}$ \\ ${ }^{1}$ Amity Business School, Amity University, India \\ ${ }^{2}$ College Of Business and Economics, Dilla University, Ethiopia
}

\begin{abstract}
This study was conducted in Gedio zone small scale enterprise financed by micro finance institution. The main objective the study was to evaluate and determine the factor that determines loan repayment performance of small scale enterprise financed by yirgachefeMFI. For the success of the study both primary and secondary data were collected to determine the loan repayment performance of small scale enterprises in Gedio zone. Questionnaire were administered to 50 borrower and manager of MFI. The data gathered are tabulated and interpreted for ease of analysis and suitability for the reader.
\end{abstract}

Keywords

repayment performance; small scale enterprises;role of micro finance institution;factors affecting loan repayment capacity of borrower; credit default issues

\section{INTRODUCTION}

Ethiopia is considered as most developing country in the eastern part of Africa Continent. Small scale enterprises (SSEs) are playing significant role in terms of employment generation, production export import etc. Most of the SSEs are facing problem like weak infrastructure, lack of entrepreneurial and managerial skills, technical knowhow and availability of finance. To fulfil the financial requirement of SSEs formal credit source is indispensable because formal financial sectors have the financial capacity to meet their growing credit demand which the informal sector is incapable to supply. Despite their importance many of them do not have sufficient access to credit from formal financial institutes. The major source of finance, especially at the start up stage is the informal sectors (i.e. from friends, relatives and local lenders). Solving the major financial constraint of this important sub sector of the economy is an important step towards achieving the national development objectives of the country. For this, the problem of high default risk, which made the financial institution reluctant to extend loan, has to be solved.

However, the majority of potentially viable SSEs still could not get credit access from formal financial institution. High transaction cost, complex bureaucratic lending procedure, elaborate paper work, high collateral requirement and delays are some of the factor which militate against effective utilization of the existing banking facilities (Aredo, 2003), Those factors make only limited number of SSEs eligible for credit from the banking sector. For the development of SSEs Ethiopian government have assigned the major task of extending medium and long term credit to small and medium scale development projects to Micro Finance Institutions.

MFI is defined as the provision of financial service to low income client including consumer and self-employed who traditionally lack access to banking and related service (Gonzaler-vege, 1998). The primary objective of micro finance institution (MFI) is to provide financial service (credit and saving) to the poor in order to release financial constraint and help to alleviate poverty.MFI is a place for the poor and near poor clients to get access to high quality financial service which include not just credit but also saving, insurance and fund transfer. MFI is a development approach that provide financial as well as social intermediation. The financial intermediation include the provision of saving, credit and insurance service while 
social intermediation involves organizing citizen group to voice their aspiration and raise concerns for consideration by policy makers and develop their self-confidence (Robinson, 2002). In Ethiopia MFIs are considered to be useful development strategy to reduce poverty having the objective to provide finance to poorest of the poor in rural as well as urban areas of the country. It is obvious that providing micro finance to poor client is costly and risky. The overall objective of MFI in Ethiopia is to increase the productive potential of the poor and poverty reduction.

However, in executing their objectives, MFI is dealing with crucial issues related toloan repayment. Problem of loan default is reducing the lending capacity of a financial institution. It also denies new applicant access to credit as the MFI cash flow management problem augment in direct proportional to the increase in default problem. Therefore, in this study we attempt to; 1) assess the factors of default in loan repayment on MFI; 2) find out the corrective measure the institution takes to solve credit default problem; and 3) identify the loan collection procedure adopted by yirgachefe MFI institution.

\section{LITERATURE REVIEW}

\section{Three c's of microcredit}

Sarah (2011) concluded in her study that the long term sustainability of MFIs is not significant as long as money was given to micro entrepreneurs and start-up assistance was given, this would imply that sustainability of the micro enterprises is more important than the long term existence of the financial institution. The three C's that should be observed to reduce default when providing microcredit: character, capacity, and capital.

Character refers to the way a person has handled past debt obligations. Paying heed to character includes determining the borrower's credit history and personal background, honesty, and reliability to pay credit debts. Considering a borrower's capacity involves determining how much debt he or she can handle comfortably by analysing income streams and identifying any legal obligations that could interfere with repayment. Capitalrefers to a borrower's current available assets, such as real estate, savings, or investments that could be used to repay debt if income is unavailable. Fasika and Daniel
(1999) found that micro and small businesses are mostly financed from household or own savings. However, these savings only help to finance businesses that require small amount of capital and mostly service-oriented activities. Investments in larger businesses require external funding and extra funding available to micro and small enterprises is borrowing from friends and relatives, which carries large number of drawbacks. Stiglitz (1990) stated that difficulties in obtaining capital, and the high cost of capital when it can be obtained, may act as important impediments to improvements in productivity. Capital markets in the rural sector often appear to be under developed.

\section{History of microfinance in Ethiopia}

Ethiopia is land of contrast. Poverty is the main challenge and a fundamental issue of economic development in Ethiopia. The solutions to poverty are multifaceted as are its causes. Many argue that an inadequate supply of credit can affect production negatively. Alleviation of poverty and promotion of economic development can therefore be facilitated through providing credit to the poor. The formal financial sector has failed to reach the majority of the rural as well as urban poor. This has forced the poor to turn to the informal and semi-formal financial sources. However, credit from such sources is not only inadequate, but also exploitative and costly. Although provision of credit to rural agricultural household for purchase of agricultural inputs and tools has since long been practiced in Ethiopia, credit schemes targeted at the urban or rural poor were non-existent until recently. Since 1970s, however, some non governmental organizations (NGOs) have been providing credit to poor households in some parts of the country, side by side with activities like delivering relief and development services (MFDR, 2011; Bediye, 1997).

According to Bediye (1997), wide scale micro-financing begun in 1990, following the credit agreement signed between the Ethiopian government and the International Development Association (IDA). The credit program was an urban micro-financing scheme that aimed at financing the Market Towns Development Project (MTDP). Since microcredit delivery and saving mobilization in Ethiopia are being carried out by NGOs, government departments, co-operatives and others in a fragmented and inconsistent way, 
the government took the initiative to establish a regulatory framework in order to facilitate sound development of the microfinance industry. Accordingly, proclamation No. 40/1996 was enacted to provide for the licensing and supervision of the business of micro-financing by empowering the NBE to license and supervise them managing for development result (MFDR, 2000).

The regulatory framework was put in place as a part of government's effort to liberalize the financial sector and lay down an alternative institutional framework to provide financial services mainly to the rural poor to boost agricultural production in order to provide food self-sufficiency and reduce rural poverty. Most importantly experts observingthe unsound financial practices of NGOs and government agencies recommended the regulatory framework to promote more systematic financial service provision and bring microfinance in the country within the existing financial system. According to National bank of Ethopia (1960) Currently, 31 MFIs have been licensed by the NBE and started delivering microfinance services since the issuance of the proclamation. These MFIs aim at poverty alleviation through targeting specific groups (reaching the poor) and group based lending. In a short period of time, the MFIs have managed to reach a significant portion of the rural and urban poor, and in so doing have gained significant experience (MFDR 2000).

According to Aredo (1993), these two institutions account for $81 \%$ of the agricultural credit. The establishments of sustainable and profitable microfinance institutions that serve large number of poor households have been a prime component of the new development strategy of Ethiopia. Wolday(2000)explained NGOs have also been directly funding

Table 1.

Demographic details of borrower respondents

\begin{tabular}{llll}
\hline \multirow{2}{*}{ Item } & & \multicolumn{2}{c}{ Respondents } \\
\cline { 3 - 4 } & & Count & $\%$ \\
\hline \multirow{2}{*}{ Sex } & Male & 32 & 64 \\
Total & Female & 18 & 36 \\
& & $\mathbf{5 0}$ & $\mathbf{1 0 0}$ \\
\hline \multirow{2}{*}{ Age } & Below 20 & - & - \\
& $21-30$ & 6 & 12 \\
& $31-40$ & 37 & 74 \\
Total & $41-50$ & 7 & 14 \\
\hline \multirow{2}{*}{ Marital status } & Above 50 & - & - \\
Total & & $\mathbf{5 0}$ & $\mathbf{1 0 0}$ \\
\hline \multirow{2}{*}{ Educational } & Single & 18 & 36 \\
Ievel & Married & 32 & 64 \\
& & $\mathbf{5 0}$ & $\mathbf{1 0 0}$ \\
Total & Pre complete & 4 & 8 \\
& Diploma/certificate & 28 & 56 \\
& BA/BSC & 9 & 18 \\
& & 9 & 18 \\
& & $\mathbf{5 0}$ & $\mathbf{1 0 0}$ \\
\hline
\end{tabular}

Table 2.

No. of dependents in household

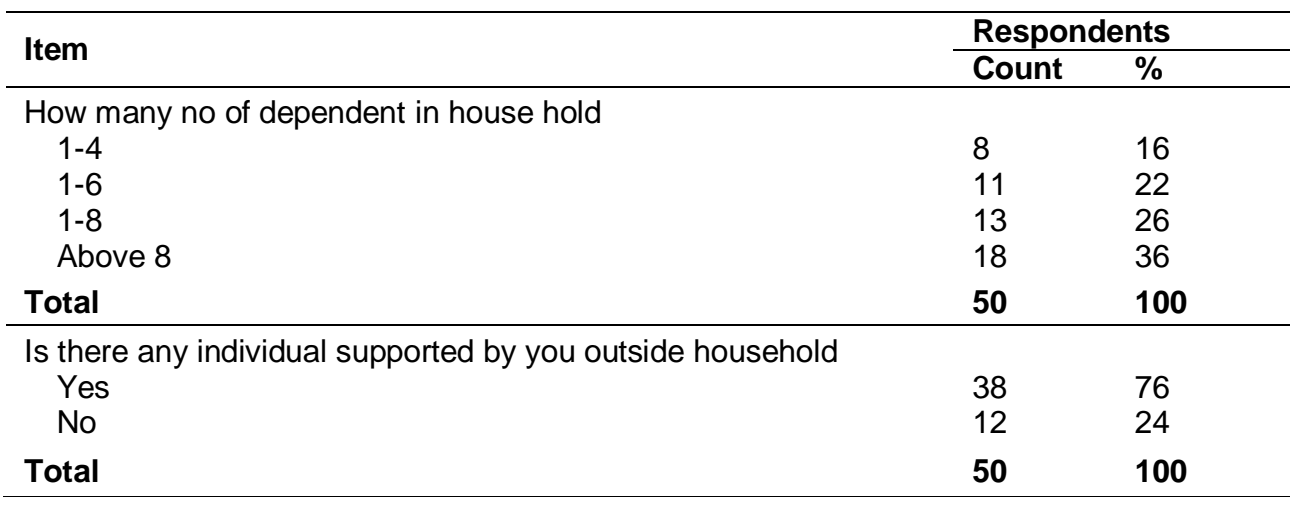


Table 3

Purpose of the loan

\begin{tabular}{lll}
\hline \multirow{2}{*}{ Item } & \multicolumn{2}{l}{ Respondents } \\
\cline { 2 - 3 } & Count & $\%$ \\
\hline For what purpose you availed the loan & & \\
$\quad$ For working capital requirements & 27 & 54 \\
$\quad$ For establishing new venture & 23 & 46 \\
Total & $\mathbf{5 0}$ & $\mathbf{1 0 0}$ \\
\hline
\end{tabular}

Table 4

Use of the loan

\begin{tabular}{lll}
\hline \multirow{2}{*}{ Item } & \multicolumn{2}{l}{ Respondents } \\
\cline { 3 - 3 } & Count & $\%$ \\
\hline Dou you use the entire loan for the intended & & \\
purpose & & \\
Yes & 42 & 84 \\
No & 8 & 16 \\
Total & $\mathbf{5 0}$ & $\mathbf{1 0 0}$ \\
\hline
\end{tabular}

microcredit activities as part and parcel of poverty alleviation program since the 1970s (MFDR, 2001). Ayana, et al. (2003) concluded in his study that during the Derg regime (1974-1991) all financial institutions were nationalized and credit was mainly channelled to public enterprises, state farms and cooperatives. The provision of credit was not based on economic rationality but entirely on government preference. The private sector was marginalized. The discrimination against the private sector was not only in credit access but also in interest rate, which was for instance $9 \%$ for private sectors as opposed to $6 \%$ for public industrial enterprises since July 1986.

Fisher and Sriram (2002) stressed that access to microfinance services protects the poor against the often severe consequences of fluctuating incomes, ill health, death and other emergency expenditures. He also noted that the credit program of POCSSBO had positive effect on income and saving of the clients. Solomon (1996) noted the banks serve big businessmen and disregard poor households as bankable. Many small, creditworthy businessmen, with their viable investment ventures, are denied access to institutional credit because they couldn't afford the required collateral. $\mathrm{He}$ also indicated that, overall; the prevailing operation of the formal financial institution in many low income countries such as Ethiopia is inefficient in providing sustainable credit facilities to the poor. Sarangi (2007) evaluated the impact of microfinance program on rural poor households in some backward regions of Madhya Pradesh in India. The findings suggested that on the one hand, many of the very poor households were excluded fromtheprogram, and on the other, the gains from participation of the program were mostly observed for the betteroff section of households, particularly those with high capital income or the large land holders. Agu (1992) analyzed the hypothesis with reference to economic performance of a banking system in Nigeria and concluded that it's a function of market structure, policy and demand variables. Economic performance in any country encompasses the profit and profitability performance of the banks. Arene C. J. (1992) concluded in his report that with environmental changes in different dimensions of farm business e.g. climate and competitiveness conditions, increasing returns in agricultural production is often defined by farmers' abilities and skills. Abraham (2002) noted that with the downfall of the Derg, the private sector got equal access to credit with other sectors, banks were also given autonomy to decide by themselves based on purely commercial criteria and establishment of private banks and insurance companies was permitted. As a result credit/loan disbursed to the private sector, which was $49 \%$ in 1992/93 rose considerably and reached $87.7 \%$ in $2000 / 01$. In fact there is still unsatisfied demand for credit from this sector of the economy due to inability to meet banks' lending requirements. Currently, the establishments of sustainable and profitable micro finance institutions that serve large number of poor households have been a prime component of the new development strategy 5 of Ethiopia NGOs have also been directly funding micro credit activities as part and parcel of poverty 
alleviation program since the 1970s (MFDR, 2001).

\section{METHODS}

\section{Data collection}

In order to collect information for finding the result the researcher would use both type of data source. i.e. primary and secondary source. This study is mainly based on primary data and supported by secondary data. Primary data is collected through questionnaire which was circulated among 50 respondents to gathered the information. Structured interview was also conducted of Branch Manager of yirgachefe micro finance institution. Secondary data was collected from yirgachefe MFI files, websites, and various reports and research done worldwide and in Ethiopia on micro finance institutions. In Gedio zone there are $5 \mathrm{MFI}$ branches and 25 sub branches. Among this one branch and 3 sub branches are located in yirgachefe area and it have 8936 borrowers. From this 158 is small scale enterprise. A sample size of 50 borrowers are selected by using simple random sampling techniques.

To reach at good conclusion and recommendation the respondent's data has been interpreted and analysed by using qualitative and quantitative techniques. The questionnaires and the raw data are analysed, presented and interpreted to give solution for the research problem .The data have been summarized and presented in tables, percentage of this data are calculated in order to facilitate the analysis. Since the data collected is more of qualitative in nature, it is presented by using descriptive analysis

\section{RESULTS AND DISCUSSION}

This study analysed a group of borrower respondents in terms of age, sex, marital status and educational level. As it is seen from item, table 1, $32(64 \%)$ of the respondents were male and while $18(36 \%)$ were female. Item 2 of table 1 shows most of the respondents are within the age group of $31-40$ which covers 37 of the 50 or $74 \%$. In terms of marital status $32(64 \%)$ of the 50 respondents were married while 18 (36\%) were single. With regard to educational level $28(56 \%)$ of the borrower were complete, $9(18 \%)$ were diploma holders, another 9 $(18 \%)$ were BA (BSC) holders and $4(8 \%)$ were pre complete.

As it can see from table 2 item 1 most of the borrower have many dependents in household and this can affect the saving habit of the borrower as shown in the table 18 $(36 \%)$ of respondent have above 8 dependents in household, 13(26\%) of respondent have 1-8 dependents in the household, 11(22\%) have 1-6 dependants and $8(16 \%)$ of respondents have 1-4 dependants in household. Thetableshows that the number of dependentswho need support from their parent is high in their family which can hinder the saving habit of the borrower. Item 2 of table 2 also shows that $38(76 \%)$ of the respondent have dependents who need care and support while

Table 5.

Loan released time

\begin{tabular}{|c|c|c|}
\hline \multirow[b]{2}{*}{ Item } & \multicolumn{2}{|c|}{ Respondents } \\
\hline & Count & $\%$ \\
\hline Did you get the loan a & & \\
\hline Yes & 18 & 36 \\
\hline No & 32 & 64 \\
\hline Total & 50 & 100 \\
\hline
\end{tabular}

Table 6.

Reasons for the loan delay

\begin{tabular}{|c|c|c|}
\hline \multirow{2}{*}{ Item } & \multicolumn{2}{|c|}{ Respondents } \\
\hline & Count & $\%$ \\
\hline Reasons for the loan delay & & \\
\hline Loan processing time & 32 & 64 \\
\hline Documents submission & 14 & 28 \\
\hline Settlement of previous loan & 4 & 8 \\
\hline Total & 50 & 100 \\
\hline
\end{tabular}


the remaining $12(24 \%)$ of the respondent does not have anydependantoutside the household. As the number of dependents increases, the borrower will need more money to fulfil their requirements in addition to the obligation of credit repayment. This can hinder the repayment performance of the borrower. They spend more of their fund to support the dependents which in turn affect their repayment.

In terms of the purpose of loan most of the borrowers lend the money for working capital. I.e.to run the on-goingbusiness and asshown in table below $54 \%$ of the borrower take the loan for working capital while the $46 \%$ of borrower take the loan to establish a new enterprise. This implies that most the borrower are taking the loan in order to run the existing business and they can generate another income before taking the loan from MFI.

The majority respondents took loan for working capital requirement. They wanted loan to solve their liquidity problem and maintain sufficient liquidity in their business. Around $46 \%$ respondents expressed that they availed the loan forstarting new smallscaleventure as they thought that micro financing will be cheap source of funding.

As shown form the above table most of the borrower spend the loan for the intended purpose. $42(84 \%)$ of the borrower use the entire loan for the purpose they took the loan while the rest $8(16 \%)$ of the borrower did not use the entire loan for the intended purpose. This shows that the borrowers also utilise the loan other than the intended purpose, this can affect the loan repayment performanceofthe borrower. Money spent for consumption is different from money spend for investment because money spend on investment have is return while money spend on consumption does not have return. So the borrowers who spend the money for the consumption have more probability of default. This implies that the one factor of loan default is using the loan for other purpose. So it is advisable to use the entire loan to the intended purpose.

As shown from table 5 and 6 , most of the borrower does not get the loan at the time the need the money. This can also affect the repayment of loan by the borrower. As shown in the table,32(64\%) of the respondent response implies the loan which is released is not released at the right time which means that they does not get the loan when the need while $18(36 \%)$ of the Respondent's response implies that they get the loan at the right time. It can be concludedthatthe MFI should release the loan to the borrower when they need the loan. The time when the loan is released also can directly affect the repayment performance of the borrower. As shown in the table most of the respondent responded that the MFI could not release the loan at the right time.Borrower were asked questions related with the reasons for loan sanction delay as per table 6 . They indicated that the reason for the loan delay is that the length of time which MFI takes to process the loan. Failure to provide the necessity document for the loan is another main cause for loan sanction delay .Also delay settlement of previous loan too affects the loan approval process. As shown in the Table $632(64 \%)$ of respondent agree that the reason for the loan delay is the length of period which the MFI

Table 7.

Visit of borrower by MFI

\begin{tabular}{llc}
\hline \multirow{2}{*}{ Item } & \multicolumn{2}{c}{ Respondents } \\
\cline { 2 - 3 } & Count & $\%$ \\
\hline Did the MFI visit after the loan released & & \\
Yes & - & - \\
No & 50 & 100 \\
Total & $\mathbf{5 0}$ & $\mathbf{1 0 0}$ \\
\hline
\end{tabular}

Table 8.

Training provide by MFI

\begin{tabular}{lll}
\hline \multirow{2}{*}{ Item } & \multicolumn{2}{l}{ Respondents } \\
\cline { 2 - 3 } & Count & $\%$ \\
\hline Did the MFI provide any training to you & & \\
Yes & 50 & 100 \\
No & - & - \\
Total & $\mathbf{5 0}$ & $\mathbf{1 0 0}$ \\
\hline
\end{tabular}


Table 9.

Duration of loan

\begin{tabular}{lll}
\hline \multirow{2}{*}{ Item } & \multicolumn{2}{l}{ Respondents } \\
\cline { 2 - 3 } & Count & $\%$ \\
\hline How many time do you take the loan from MFI & & \\
For the first time & 42 & 84 \\
For the second time & 8 & 16 \\
For the third time & - & - \\
More than three time & - & - \\
Total & $\mathbf{5 0}$ & $\mathbf{1 0 0}$ \\
\hline
\end{tabular}

Table10.

Repayment of loan

\begin{tabular}{lll}
\hline \multirow{2}{*}{ Item } & \multicolumn{2}{l}{ Respondent } \\
\cline { 2 - 3 } & Count & $\%$ \\
\hline Did you believe the loan you take can be repaid & & \\
Yes & 50 & 100 \\
No & - & - \\
Total & $\mathbf{5 0}$ & $\mathbf{1 0 0}$ \\
\hline
\end{tabular}

provide to process the loan. $14(28 \%)$ of respondents responded that the reason of loan delay is failure of timely providing the necessary documents and the rest $4(8 \%)$ of respondent answered that delay in settlement of the pervious loan is also a significant cause foran approval.

As shown from table 7 , the micro finance institutions do not visit the borrowers after theysanction the loan. Visiting the borrower is crucial to know the economic condition of the borrower and also to know the financial condition of the borrower, this can help the MFI to predict how can the borrower can repay the loan. Visitingthe concerned borrower is important to know if the financial condition is strong, if not then MFI have to find out the measures to protect the loan from default. It can be observed from the table below that the MFI does not visit the borrower .The probability of using credit funds for nonintended purposes decreases if adequate credit supervision is made regarding credit/loanutilization.

As shown from the table 8 all the respondents responded that the MFI provide training to the borrower. This implies that the MFI can provide training before the approval of the loan, this helps the borrower to utilise the loan effectively and to use the loan for the intended purpose. Furthermore training is one tool for skill development so the borrower can develop their skill and also they can learn how to manage their business as well as how to manage their loan in order to get high returns.

As shown in the table 9 below, 42 (84\%) of the respondents take the loan from MFI for the first time while the rest of the borrower 8 $(16 \%)$ of the respondent take the loan for the second time. Repetition of the loan tells us the good reputation and repayment of the loan by the borrower. I.e. if the borrower defaults in the first loan it is not advisable to give another loan. As can be seen from table below that most of the borrowers take the loan for the first time and there are only $16 \%$ borrowers who availed the funding for second time. Borrower who can repay the first loan can take the other loan from MFI.

As shown from the table 8 all the respondents responded that the MFI provide training to the borrower. This implies that the $\mathrm{MFI}$ can provide training before the approval of the loan, this helps the borrower to utilise the loan effectively and to use the loan for the intended purpose. Furthermore training is one tool for skill development so the borrower can develop their skill and also they can learn how to manage their business as well as how to manage their loan in order to get high returns.

As shown in the table 9 below, 42 (84\%) of the respondents take the loan from MFI for the first time while the rest of the borrower 8 $(16 \%)$ of the respondent take the loan for the second time. Repetition of the loan tells us the good reputation and repayment of the loan by the borrower. I.e. if the borrower defaults in the first loan it is not advisable to give another loan. As can be seen from table below that most of the borrowers take the loan for the first time and there are only $16 \%$ borrowers who availed the funding for second time .Borrower who can repaythe first loan can take the other loan from MFI. 
Table 11.

Repayment period

\begin{tabular}{lll}
\hline \multirow{2}{*}{ Item } & \multicolumn{2}{l}{ Respondents } \\
\cline { 2 - 3 } & Count & $\%$ \\
\hline Is the repayment period enough & 43 & 86 \\
Yes & 7 & 14 \\
No & $\mathbf{5 0}$ & $\mathbf{1 0 0}$ \\
Total & & \\
\hline Which time is suitable for you & 25 & 50 \\
Jan -April & 15 & 30 \\
May- August & 10 & 20 \\
Sep- Dec & $\mathbf{5 0}$ & $\mathbf{1 0 0}$ \\
Total & & \\
\hline
\end{tabular}

Table 12.

Failure to repay the Ioan

\begin{tabular}{lll}
\hline \multirow{2}{*}{ Item } & \multicolumn{2}{c}{ Respondents } \\
\cline { 2 - 3 } & Count & $\%$ \\
\hline Have you ever failed to repay the loan & 32 & 64 \\
Yes & 18 & 36 \\
No & $\mathbf{5 0}$ & $\mathbf{1 0 0}$ \\
Total & & \\
\hline How many time did you fail for those who failed to repay (32 respondents) & & 13 \\
Once & 4 & 38 \\
Two time & 12 & 50 \\
Three and more & 16 & $\mathbf{1 0 0}$ \\
Total & $\mathbf{3 2}$ & \\
\hline
\end{tabular}

According to table 10, all the respondents were agreeing that they can repay the whole amount of loan taken from MFI on its maturity time. This implies that all the borrowers have the capacity to repay the loan on time and have positive attitude and emotion to repay the loan.As shown from table 11 the respondents responded that the repayment period is enough to repay the loan. The MFI give enough repayment period to repay the loan but the repayment period is not suitable to most of the borrower. As per their response, the borrowersprefer repayment timing from January - April. But as the MFI repayment period is all time throughout the year. This can affect the borrower's ability to get the return especially at the time when the trade is good in the month between OctoberFebruary. If borrowers find the repayment period suitable, they can utilize the credit proceeds effectively for the intended purpose than those who regard the period of repayment unsuitable.

As shown in table No. 12, most of the respondents failed to repay the loan according to the payment period. This study shows that the MFI borrowers do not repay the loan on the time. According to the table $12,32(64 \%)$ of the respondent fail to pay the loan and remaining respondent 18(36\%) can repay the loan at the time of maturity.
The main reason for such failure is unsuitable timing given by MFIs. Out of total 32 respondents, who failed to repay the loan when asked, indicated that how many times they failed to reply the loan. Out of 32 borrowers, $50 \%$ borrowers failed more than three times and only $13 \%$ failed onlyonce.

According to the table $13,29(58 \%)$ respondent agreed that they fail to repay the loan because ofthe market problem in the city. $13(26 \%)$ respondent answered that they fail to repay the loan because of working capital shortage which they faced during their business cycle. The rest $8(16 \%)$ of respondent agree that the reason for the failure of the loan to repay is the technical problem in their business.

\section{Interpretation and analysis of interview question}

To conduct this study, interview was conducted at Yirgachefe branch of MFI. Branch managers of MFI were interviewed by the researcher to make the study more purposeful and meaningful. The managers were willing to respond the questions. Respondents were associated with MFI from last four years eight months as a Branch Manager and served on various other 
Table 13.

Reasons for loan repayment failure

\begin{tabular}{lll}
\hline \multirow{2}{*}{ Item } & Respondents \\
\cline { 2 - 3 } & Count & $\%$ \\
\hline Reasons for loan repayment failure & & 58 \\
Market condition & 29 & 26 \\
Working capital shortage & 13 & 16 \\
Failure of previous loan repayments & 8 & $\mathbf{1 0 0}$ \\
Total & $\mathbf{5 0}$ & \\
\hline
\end{tabular}

positions from last 10years and having 14years of overall experience of banking industry. This shows that they have worked in this institution for long period of time and have extensive work experience. There are 8936 borrower in yirgachefe MFI and 158 are small scale enterprises. Respondents discussed the eligibility criteria for getting loan. Following condition should be fulfilled to get loan: 1) an identification card which shows that the applicant is resident of yirgachefe; 2) if the applicant is a business group, PLC, social institution like Edir, cooperative society or any other organization must present a document which shows it has a legal personality and it located in yirgachefe; 3) the applicant should not have any unsettled loan from any institution; 4) if the applicant excluding business group, is requesting for loan greater than 5000 birr, it has to produce trade license.

Respondent have replied that the loan have to be fully settled down within 36 months. Borrower should repay the loan according to the schedule provided by the institution. The repayment schedule is not selected by the borrower. The suitability of repayment period can directly affect the loan repayment so the MFI should work to mitigate this problem. Respondents discussed the probable reasons of default in payment of loan. The respondentsexplained that they can provide the loan according to the schedule but because of market problem and diversion of loan by the borrower, the default of loan occurs. Therefore it is concluded that the MFIS should investigate the market problem before the approval of loan. Respondents also replied that the MFI use group lending mechanism to reduce loan default. In group lending mechanism if somebody from group member is a defaulter to repay the loan the rest member of the group have to take the obligation to repay the loan. By group lending mechanism all member of the group have a duty to repay the loan.To retain the default loan they give another loan as a working capital to retain the default borrower. Respondentsindicatedthat the repayment period and the schedule is fixed by the procedure of the institution and the works according to the procedure. So the institution revises the procedure in order to make better repayment schedule for the borrower. Respondents concluded that it is the duty of loan officer to visit the borrower and analyse their repayment performance

\section{CONCLUSIONS}

The present study concluded based on both primary structured questionnaire and in depth interview that credit default problem is the major issue faced in Ethiopia, thus hindering the loan approval process from MFIS. Gedio zone small scale enterprise is financed by micro finance institution and after in depth analysis, it was found there are various significant factors affecting the credit defaultissues in borrowers. Though the borrowers have both the capacity and willingness to repay the loan, even then they find it difficult to repay loan on time due to cumbersome loan collection procedure. Factors like credit/loan size, and credit diversion, credit/loan supervision, and suitability of credit repayment period, bad market conditions, liquidity problem, high No of dependents and low income etc. causes loan default among borrowers. The evidences in the study reveal that the overall default performance of the borrowers and the screening technique, which the lending institutions follows to ration credit to its clients, were more or less found to be sound. Similarly, it was found that the credit scheme has contributed positively in terms of improving the incomes, access to health facilities and nutritional status of the borrowers. The study also found out that delays in disbursing funds to borrowers may be as prompt as two months from the time a loan application is filed. Timely disbursement enables a borrower to match acquired 
resources to business needs. With such delays, there is a possibility that business priorities and market conditions will change by the time funds are received. That situation can lead to a diversion of funds for some unprofitable uses and so to an increased chance of credit default. The extra significant determinant that was found to undermine the repayment performance was loan size. This implies that there is a need to determine an appropriate loan amount that just suffices the project cost or purpose of the borrowing, through a rigorous investigation of the demand for credits and plans submitted by borrowers. .Credit diversion was found to be one of the important and significant factors influencing credit default negatively, i.e. it increases default risk significantly. This variable is itself influenced by many factors, of which loan supervision, education and suitability of repayment period were found to reduce the probability of diverting credit to non-productive uses.

\section{Recommendation}

This study found that improving the selected MFIs performance is a prerequisite to make it more effective in carrying out its mandate and providing technical support to microenterprises so as to improve their profitability. At the end, the selected MFIs of Ethiopia should consider the following recommendations: 1) srengthening its management information systems to produce up-to-date credit/loan repayment statements for borrowers and to enable early detection of potential default problems. Doing so will help the MFIs take quick follow-up actions, such as providing debt counselling or issuing demand notices; 2) training the staff by enhancing the capacity of computer applications. This will enable optimal use of the available computer facilities, speed up loan processing, and ensure timely disbursements and collection of credits;3) continuousfollow-up on borrowers to improve recovery of outstanding loan balances; 4) revise its borrower's credit appraisal instruments in order to help identify deserving but vulnerable micro-entrepreneurs. Vetting should determine how much debt the borrower can handle comfortably, his or her income streams, and any other obligations that might interfere with repayment. Thus will enable the selected MFIs board to provide the borrower with appropriate counselling and support to avoid credit default; 5) rationing those with more income could be seen, as a deliberate pro-poor action on the part of the lending institutions, if at all it is done with such an intention. On the other hand, the majority of the institution's clients whose eligibility for participation in the scheme is based on the criteria of being poor are illiterate. Since most of the time literacy and wealth are positively related, and that it seems that the selected lending institutions are focusing more on equity than efficiency by rationing the literate clients more strictly than the illiterate ones.

\section{Further study suggestions}

There are a number of issues which require further research. This study is focused on credit default risk of MFIs in Gedio zone. The relevance of the findings of the study perhaps limited with the selected yirgachef MFIs. Since the data collected for this study is very limited, this finding needs to be further studied. Also there may be a need to test statistically if there is some sort of association between credit repayment and purpose of borrowing

\section{REFERENCES}

Abraham, G .(2002). Loan repayment and its determinants in small-scale enterprises financing in Ethiopia: Case of private borrowers around Zeway Area, Msc, Thesis, Addis Ababa University

Agu, C. C. (1992). Analysis of the determinants of the Nigerian banking system's profits and profitability performance. Journal of Savings and Development, 16(1), 353370.

Aredo, D. (1993). The informal and semi-formal financial sectors in Ethiopia: a study of the lqqub, Iddir, and savings and credit co-operatives. African Economic Research Consortium Research Paper 21Nairobi,African economic research consortium.

Aredo, D. (2003). Informal Financial Institution: The economic importance of Iddir, lqqub, and Loans, Proccedings of National Workshop on Technological Progress in Ethiopia. Agriculture, Nov, 20-30.

Arene, C .J. (1992). Loan repayment and technical assistance among smallholder maize farmers in Nigeria, African review of money, finance and banking. $A$ supplement of savings and development journal,1,65-70 
Ayana, I., \& Tsegaye, T. (2003). Governance and ownership structure of microfinance institutions in Ethiopia (No. 8). Association of Ethiopian Microfinance Institutions.

Bediye, M. (1997). Determinants of microenterprise loan repayment and efficiency of screening mechanism in urban Ethiopia: the case of Bahir Dar and Awassa Towns. Addis Ababa, 20.

Fasika, D., \& Daniel, A. (1999).financing micro and small scale enterprises: an empirical survey in urban Ethiopia. Ethiopian Journal of Economics, 6(1), 104-104.

Fisher, T. and M.S. Sriram. (2002). Beyond MicroCredit: Putting Development Back into Microfinance. Vistar Publications: New Delhi. Pp325-360

Gonzalez-Vega, C. (1998). Microfinance: broader achievements and new challenges. Economics and sociology occasional paper No. 2518. Rural finance program. Department of agricultural, environmental, and development economics. The Ohio State University.Ohio, USA

Guntz, S. (2011). Sustainability and profitability of microfinance institutions. CAIFD-Center for Applied International Finance and Development, Research Paper, 4.

Micro Finance Development Review (2000), Vol. 1, No.1, Addis Ababa

National Bank of Ethiopia (NBE), Annual Reports, 1960/61-1998/99 and Unpublished Data
Robinson, M. (2002). The microfinance revolution volume 2: lessons from Indonesia. Washington, DC:The World Bank.

Sarangi, N. (2007, February). Microfinance and the rural poor: impact assessment based on fieldwork in Madhya Pradesh, India. In Conference on Sustainable Development \& Livelihoods, Delhi School of Economics, Delhi (pp. 6-8).

Solomon, D. (1996). Credit to Poor Households: The Case Of Financing Micro Enterprises In Debre-Berhan Town, North Showa. In The Ethiopian Economy: Poverty and Poverty Alleviation. Proceedings of the Fifth Annual Conference on the Ethiopian Economy. Addis Ababa.

Stiglitz, J. E. (1990). Peer monitoring and credit markets. The world bank economic review, 4(3), 351-366.

Wolday, A. (2000). Review of Microfinance Industry in Ethiopia: Regulatory Framework and Performance. Association of Ethiopian Microfinance Institutions (AEMFI). Occasion paper, (2). 